\title{
The external dimension of the European Union's energy policy and practice of German energy policy
}

\section{Introduction}

The security of energy supply is crucial for the economic and social development of the Member States, and hence the European Union (EU) as a whole. Although the European Union reduces the use of fossil fuels for energy production, yet it is still dependent on them. Eurostat data shows that in 2016 about three-quarters of energy consumption in the EU was covered with fossil fuels. Coal, oil and natural gas are still the basis for energy production for most EU countries. Energy production from fossil fuels in the EU is increasingly dependent on imports. In 2016, 77.1\% of imported natural gas came from Russia, Norway and Algeria, and $68.2 \%$ of imported solid fuels came from Russia, Colombia and Australia. On the other hand, crude oil imports were slightly less concentrated among major suppliers, as the total share of Russia, Norway and Iraq was 52.6\% (Eurostat, 2018, pp. 27-36). EU energy supply security, in the face of dependence on energy imports, is determined by external factors such as the development of production/ exports in third countries, the modernization of existing infrastructure and the emergence of new supply and transit routes. That is why it is so important to develop relations with third countries (producers, consumers and transit states), which is the essence of the external dimension of the European Union's energy policy.

Although the Treaty of Lisbon leaves the external energy policy essentially within the competence of the Member States, it nevertheless created the basis for developing the external dimension of EU energy policy. In other words, the Treaty of Lisbon does not limit EU competence in this area. The European Union may conclude agreements with external suppliers; article 216 (1) of the Treaty on the Functioning of the European Union (TFEU) states that "the Union may conclude an agreement with one or more third countries or international organizations ... where the conclusion of an agreement is necessary in order to achieve, within the framework of the Union's policies, one of the objectives referred to in the Treaties [...]" (TFEU, 2016, p. 144). However, article 171 (3) TFEU states that "the Union may decide to cooperate with third countries to promote projects of mutual interest and to ensure the interoperability of networks" (TFEU, 2016, p. 125). Member States may use their own energy resources and provide external supplies of fossil fuels as well as shape the structure of primary energy consumption (article 194 (2) TFEU) (TFEU, 2016, p. 134).

Germany is the largest energy consumer in the European Union. Systematically declining domestic reserves as well as the volume of fossil fuel extraction causes de- 
pendence on their supplies from abroad. Despite the diversification of energy supply through the development of renewable energy sources, reliance on imports of energy resources is high. Therefore, the problem of ensuring stable supplies of energy resources is taken into account in Germany's foreign policy. In this context, the quality of relations with producers and potential alternative suppliers of energy resources as well as with transit states and with countries with growing energy demand is of particular importance.

The aim is to present some aspects of shaping the external dimension of the EU energy policy and strategic directions and practice of the energy policy of one of the key member states - Germany. The article will discuss the beginnings and development of the external dimension of the European Union's energy policy, including its directions, objectives and instruments. Germany's position on the external dimension of EU energy policy will be presented as well as goals in Germany's bilateral cooperation with producers, consumers and transit countries for energy raw materials, its forms and instruments. Factor, content and historical-comparative analysis as well as elements of decision-making and institutional(-legal) methods were used. The article is based on the primary sources, studies and the author's individually conducted research. ${ }^{1}$

\section{The beginnings and development of the external dimension of the European Union's energy policy}

Initially, the external dimension did not play a significant role in the development of EC/EU energy policy. Since the failure of joint activities in the context of oil crises in 1973 and 1979-1982, the Commission has not taken initiatives in this field. It was not until 29th November, 2000 that the Commission submitted a Green Paper in which the challenges of energy policy were articulated, and its external dimension was taken into account. The Commission stressed that the EU is highly dependent on the supply of energy resources from external sources and called for the creation of a security of supply strategy that would minimize this dependence (Commission of the European Communities, 2000). The postulate formulated in the Green Paper has been concretized in subsequent years in the Commission Communications and Council Conclusions in the form of priorities for the EU's external energy policy. It is worth mentioning that the European Security Strategy adopted on 12th December, 2003, in which the issue of energy supply was referred to in the context of global challenges and threats. The document did not answer the question how the European Union should respond to challenges, only the need for stability of its neighborhood was mentioned, which may positively affect the security of energy supply, if it covers suppliers and transit countries for energy resources (ESS, 2003). Thus, the issue of energy supply has been integrated into the sphere of security policy.

In the European Commission's Communication published on 26th May, 2003, the following main directions of the external energy policy were indicated: Russia (the

${ }^{1}$ The research was co-financed from funds allocated for the statutory activity of the Faculty of Law, Administration and International Relations of the Andrzej Frycz Modrzewski Krakow University no. WPAiSM/DS/5/2018. 
main supplier to the EU of crude oil, natural gas and solid fossil fuels), Euro-Mediterranean region, Southeastern Europe, the Caspian region and the Northern Area (Baltic Sea countries). In addition, Ukraine was mentioned as an important EU partner (Commission of the European Communities, 2003).

The Green Paper of 8th March, 2006 has brought major progress with regard to the essence of the external dimension of EU's energy policy. For the first time the European Commission has called for a coherent external energy policy; first of all, it proposed setting priorities for the creation of new infrastructure necessary to ensure the security of energy supply in the EU, a pan-European Treaty of the Energy Community, a new energy partnership with the Russian Federation, deepening relations with major energy producers and consumers, and an international agreement on the rational use of energy (Commission of the European Communities, 2006a).

The Conclusions of the European Council of 23rd/24th March, 2006 included for the first time an extensive chapter on energy policy and its external dimension (Part Two European Energy Policy) (Council of the European Union 2006). It was emphasized that increasing the security of supply is possible "development of a common external policy approach in support of energy policy objectives [...]." In the context of "the possibility of development a common approach," the emphasis was put on the diversification of suppliers and supply routes by the Member States. Importantly, diversification should concern external sources as well as cover the development and use of local energy potential and energy efficiency. In Annex III activities related to internal and external dimensions of energy policy were mentioned.

In response to the demand of the Summit of Heads of State and Government Javier Solana, EU High Representative for the CFSP, and the European Commission submitted in June 2006 the document "An External Policy to Serve Europe's Energy Interests," which for the first time outlined the principles and objectives of the EU's external energy policy (Commission/SG/HR for the European Council, 2006). These included, among others: energy partnerships with third countries, including infrastructure development and access to production and exports for European industry while ensuring investment security; improving conditions for energy trade; physical security of energy infrastructure including environmental protection standards; international cooperation in renewable energy sources, energy efficiency and climate change; diversification of energy imports, broken down into energy and state carriers, support for strategic reserves that could be maintained with partner countries. Energy efficient markets should be served by efficiently functioning markets and diversification of sources and routes of supply.

In the Communication "External relations in the area of energy - from principles to action" from 2006, the European Commission stressed the need for "between the internal andexternal aspects of energy policy, and between energy policy and other policies that affect it" and coordination "positions of the Member States and the Commission in order to speak with an effective, common voice." Russia played a particular role in the document, in connection with the need to negotiate a new framework agreement in the context of the continuation of the Partnership and Cooperation Agreement (PCA). The establishment of a network of states operating on the basis of common rules of the internal market was recognized as important throughout the EU. 
In addition, in the context of diversification, the Nabucco gas pipeline project was mentioned for the first time (Commission of the European Communities, 2006b).

In the Communication "An energy policy for Europe" given on 10th January, 2007, the European Commission stated that energy should become a central part of the EU's external relations, because it is significant for geopolitical security, economic stability, social development and international efforts to protect the climate (Commission of the European Communities, 2007). The importance of "speaking with one voice" was confirmed. Annex 1 included the priorities of the EU's external energy policy for the next three years.

During the German Presidency of the EU Council in March 2007, the "Action Plan for 2007-2009" was adopted, based on the EC communication of 10th January, 2007, which called for a faster development of a common concept of the external dimension of energy policy. The document set out the directions of EU energy policy at the international level. The following aspects were considered essential for the development of the EU common position: the negotiation and finalization of the agreement with Russia that would apply after the expiration of the PCA and, in particular, that would address energy issues; deepening relations with Central Asia, the Caspian and Black Sea regions, regions important for the diversification of sources and supply routes; deepening partnership and cooperation on the basis of bilateral energy dialogues with the US, China, India, Brazil and other emerging economies, where the focus would be on reducing greenhouse gas emissions, rational energy use, renewable energy sources and low-carbon technologies; implementation of the Energy Community Treaty with the possibility of extending to Norway, Turkey, Ukraine and Moldova; using instruments under the European Neighborhood Policy (ENP); deepening energy relations with Algeria, Egypt and other producers in the Mashreq and Maghreb region, as well as promoting access to energy (Council of the European Union, 2007).

On 13th November, 2008, the European Commission presented "Second Strategic Energy Review. An EU Energy Security and Solidarity Action Plan." It underlines the need to step up efforts to develop an effective external energy policy, identify the infrastructure of greatest importance for the EU's energy security and ensure its emergence, and coherent action to deepen partnerships with key energy suppliers and consumers and transit producers. The European Commission has proposed a five-point action plan on energy security and solidarity in the European Union: infrastructure needs and diversification of energy supply; external relations in the field of energy; oil and gas stocks as well as crisis response mechanisms; energetic efficiency; optimal use of the EU's own energy resources." Regarding the promotion of infrastructure development, the EC proposed the adoption of six key actions as Community priorities: the Baltic Interconnection Plan; construction of the Southern Gas Corridor, to which the raw material would be delivered from the Caspian Sea region and the Middle East; liquefied natural gas (LNG) and storage of sufficient quantities of gas; completing the construction of the Mediterranean energy ring linking Europe with the southern part of the Mediterranean; the development of interconnections from north to south in Central and Southeastern Europe; Blueprint for a North Sea Grid (Commission of the European Communities, 2008). 
On 28th January 2009, the EC proposed to the EU Council an investment package in the energy sector worth EUR 3.5 billion. Half of this amount was to be allocated to gas and electricity connections, interconnectors and the Southern Gas Corridor. At the same time, approximately 245 million EUR were allocated to the Nabucco pipeline, and 105 million EUR to the Greece-Italy interconnector. During the summit on 19th20th March, 2009, it was decided to allocate 200 million EUR to the Nabucco gas pipeline (Council of the European Union, 2009).

The Russian-Ukrainian gas crisis at the beginning of 2009 resulted in the issue of energy security at the above-mentioned summit. External energy policy has been taken into account in the context of security of supply. The Conclusions stated that "[...] in order to deliver on energy security, the EU collectively, as well as each Member State, must be prepared to combine solidarity with responsibility." Thus, for the first time, the solidarity aspect in the EU energy policy was emphasized. In connection with the need to develop energy infrastructure and interconnections, the European Commission was asked to present, in cooperation with the Member States, specific actions necessary to achieve the objectives set out in "Second Strategic Energy Review" (Council of the European Union, 2009). The Southern Gas Corridor has only been mentioned in this context. It resulted, among others, from the resistance of the federal government of Germany, representing the position that the project should not be subsidized from public funds. The federal government questioned the economics of the project as well as the possibility of gas supplies from Iraq or Iran. Germany would not directly benefit from Nabucco's gas supplies; therefore the project was not on the list of priorities. Hence, Germany did not oppose the recognition of the European importance of the project, but it was also not active in accelerating its implementation (Rompel, 2015, p. 522). The Conclusions contain provisions referring to the urgent need to create adequate crisis response mechanisms in the EU, as well as obtaining from suppliers and transit in order to deliver on energy security, the EU collectively, as well as each Member State, must be prepared to combine solidarity with responsibility appropriate guarantees that gas supplies will not be interrupted (Council of the European Union, 2009).

The hitherto achievements were not satisfactory, and the summit on 4th February, 2011 was largely devoted to energy policy, with the external energy policy being given a central role. The need to modernize and expand energy infrastructure was emphasized, "[...] This is crucial to ensure that solidarity between Member States will become operational, that alternative supply/transit routes and sources of energy will materialise [...]." This is in fact the key "This is crucial to ensure that solidarity between Member States will become operational, that alternative supply/transit routes and sources of energy will materialise [...]." It underlined the importance of better coordination of EU and Member States' efforts to ensure coherence in external relations with key producers, consumers and transit countries. In addition, energy security should be included in the EU's neighborhood policy. The EU should develop energy partnerships with key players and around strategic corridors on all topics of common interest. Additionally, the issue of "encouraging" neighboring countries to adopt EU principles of the internal energy market, especially through the extension and deepening of the Energy Community Treaty, as well as promoting initiatives for regional cooperation, was highlighted (Council of the European Union, 2011a). 
In order to strengthen the external dimension of energy policy, the European Commission published on 7th September, 2011 Communication "The EU Energy Policy: Engaging with Partners beyond Our Borders." The document sets out a comprehensive external energy policy together with the legal and political instruments available to the European Union in this area. In the context of creating a comprehensive system of EU energy partnerships, the approach and flexibility in terms of defining the scope and selection of instruments that should be adapted to the state or organization are emphasized. The EC proposed a cooperation strategy based on the following priorities: 1) developing the external dimension of the EU internal energy market, 2) strengthening partnerships for secure, safe, sustainable and competitive energy supply, 3) improving access of developing countries to sustainable energy, 4) increasing support for EU policy beyond its borders (European Commission, 2011). The above proposal was a response to the request of the European Council of 4th February, 2011 to further increase the consistency and coherence of external energy activities, given their contribution to the objectives of the European Union's energy policy.

Novum in the document of 7th September, 2011 was to relate the goals of external energy policy with development policy. Supporting developing countries in the area of energy is also important for the implementation of EU economic interests (export of technologies for the needs of renewable energy) (Rompel, 2015, p. 288).

EU's security of energy supply is strengthened through efforts to develop local renewable energy sources, improve energy efficiency and diversify sources and routes of supply, as well as through developing cooperation with existing European suppliers (European Commission, 2013). The external energy policy defined in 2011 gave rise to many EU initiatives in this field.

The outcome of the debate on the directions of development of the external energy policy were the conclusions of the Transport, Telecommunications and Energy Council of 24th November, 2011. Defined in them, inter alia, market rules applicable in external relations, the most important infrastructure projects enabling the supply of raw materials from outside the EU, as well as the rules of EU Member States cooperation in international fora (including IEA and IRENA). In the document once again the priorities of the external energy policy include close cooperation with third countries using multilateral instruments (strengthening the Energy Community, deepening cooperation with the parties of the Energy Charter Treaty), cooperation with countries from North Africa, the Middle East and the Caspian region, the Eastern Partnership and the Black Sea region, as well as deepening energy partnerships (Council of the European Union, 2011b). The external dimension of EU energy policy should ensure security of supply as well as diversification of suppliers, transportation routes and energy sources (priority projects include the Southern Gas Corridor, the Eastern Corridor and the Mediterranean area). It was noted that the internal energy market is a prerequisite for an effective external energy policy. It is important to support a sustainable and climate-friendly energy policy in developing countries (renewable energy sources, energy efficiency). The EU's external energy policy was to be consistent with the strategy of transition to a low-carbon economy by 2050. The Conclusions of the Transport, Telecommunications and Energy Council were approved on 9th December, 2011 by the European Council (European Council, 2011). 
On 22nd May, 2013 (for the first time since 2011), the European Summit was devoted to energy policy, with the reference to external energy policy only stating that "[...] Member States will enhance their cooperation in support of the external dimension of EU energy policy" (European Council, 2013).

The issues of external energy policy and its instruments have been included in the strategy of the Energy Union. In the European Commission's Communication of 25th February, 2015 "A Framework Strategy for a Resilient Energy Union with a Forward-Looking Climate Change Policy" was written, inter alia, that "the EU will use all foreign policy instruments to establish strategic energy partnerships with increasingly important producing and transit countries or regions such as Algeria and Turkey, Azerbaijan and Turkmenistan, the Middle East, Africa and other potential suppliers." The European Union will develop partnership with Norway, the USA and Canada. It was announced to consider rephrasing "energy relations with Russia based on a level playing field in terms of market opening, fair competition, environmental protection and safety" as well as "[...] to strengthen of the Energy Community, ensuring effective implementation of the EU's energy, environment and competition acquis, energy market reforms and incentivising investments in the energy sector" (European Commission, 2015).

In the document "Shared Vision, Common Action: A Stronger Europe. A Global Strategy for the European Union's Foreign And Security Policy" of 2016 in relation to energy security states that the Energy Union is an integrated action for the internal and external aspects of European energy security. It was noted that the aim is to diversify "its energy sources, routes and suppliers, particularly in the gas domain, as well as to promote the highest nuclear safety standards in third countries." Therefore, support for the construction of infrastructure enabling the diversification of sources of supply to European markets was announced. It was also noted that agreements with third countries on infrastructure "can have a differentiated impact on the security of supply within the Union or hinder the functioning of the internal energy market." Hence, the need for transparency of such agreements and the compatibility of new infrastructure elements with the third energy package were emphasized (Mogherini, 2016, pp. 19-20). In the Council conclusions on Implementing the EU Global Strategy - strengthening synergies between EU climate and energy diplomacies and elements for priorities for 201 adopted on 6th March, 2017, it was postulated to include the climate and energy goals for EU partnerships with financial institutions as well as other multilateral organizations and fora. In accordance with the Paris Agreement and the Energy Union Framework Strategy, all local resources and safe low-carbon technologies were considered significant (Council of the European Union, 2017).

The diversity of energy mixes, the specific structure of production and transport of energy raw materials, as well as the varying degree of dependence of the EU Member States on the import of energy resources and relations with their countries of origin, hinder a coherent and effective external energy policy. Lack of a common position towards suppliers results from diversified supply sources and the volume of imported energy raw materials by the EU Member States. The gas imported by the countries of Central, Eastern and Southeastern Europe comes mainly from Russia. While, for example, the United Kingdom has been based on its own extraction so far, supplement- 
ing the deficit with imports from Norway, and Spain predominantly on supplies from Algeria, Nigeria and Qatar. In addition, only some Member States have LNG terminals, including Belgium, France, Greece, Italy, Lithuania, the Netherlands, Poland, Portugal, the United Kingdom, Spain and Malta (LNG in Europe, 2018). Regional dependence on supplies is a problem not only at the national level, because also energy companies are often associated with suppliers through long-term contracts [e.g. contracts for the natural gas supply to Germany were concluded with Gazprom by the following companies: E.ON (four contracts until 2035), Wingas (contract until 2030) and VNG (contract until 2030)]. It is difficult for the common position of the Member States due to often conflicting interests, as in the case of Nord Stream 1, and currently Nord Stream 2, which, inter alia, Poland and the Baltic states perceive it as a project threatening their energy security. In addition, natural gas transport causes dependence on transit countries. Diversification is hampered by the production and transport infrastructure originating from the Soviet times, which is not sufficiently developed and often needs modernization. And natural gas storage is expensive and associated with specific geological conditions (Rompel, 2015, p. 218; Heinecke, 2016, pp. 81-82).

Among the factors hindering the development of the external energy policy, the unfinished construction of the internal energy market and the insufficiently developed gas energy transmission systems (and electricity) are mentioned. The completion of the internal gas market (and electricity) has long been one of the objectives of the EU's energy policy. The liberalization of the gas (and electricity) market in the EU was initiated in the early 1990s, and at the beginning of the 21 st century, the emphasis was shifted to the integration of markets into the common energy market. "Speaking with one voice" to external suppliers implies unity within the European Union, hence the common energy market is a prerequisite. The extensive infrastructure, especially cross-border connections, would facilitate the transfer of energy between EU Member States and thus contribute to ensuring security of supply and better integration of energy markets. The degree of network expansion in the gas (and electricity) sector is so far insufficient. Shortages in the infrastructure make it difficult not only to complete the completion of the internal energy market, but also to effectively use renewable energy sources. Transmission networks play an important role in the EU's external relations. Energy projects will be enhanced by projects that would provide new suppliers as well as new supply routes (Southern Gas Corridor), which contribute to the achievement of the Energy Union. However, for the EU to benefit from these supplies, it is necessary to create an internal distribution infrastructure for the raw material (Heinecke, 2016, pp. 84-85).

The EU's energy policy is focused principally on the diversification of sources and routes of supply (mainly natural gas). Therefore, the instruments of the external dimension of the energy policy include energy partnerships with producers and transit countries to create stable conditions necessary to implement specific projects in the scope of diversification of energy sources supply. Bilateral cooperation with large energy consumers in the area of "clean energy technologies," increase of energy efficiency and development of renewable energy sources in the context of combating climate change and access to new energy sources (e.g. in 2017 the following documents were signed: Work Plan 2017-2018 of the EU-China Roadmap on Energy Cooperation, Memorandum of Cooperation between the EU and Japan on Promoting and 
Establishing a Liquid, Flexible and TransparentGlobal LiquefiedNatural Gas Market and EU-India Joint Statement on Clean Energy and Climate Change) as well as in international organizations and and other multilateral cooperation fora are important.

The EU's external energy policy oscillates between extending the principles and structures of the internal energy market to countries and regions outside the EU (standards, principles and institutions as tools for integrating the energy market in Europe to improve energy security), and bilateral agreements between Member States and energy producers. From the perspective of the European Union, it is justified to create a "space of common rules" outside the EU, thanks to which the markets will become predictable and transparent, which in turn should lead in the long run to increasing the security of energy supply. This strategy is reflected in the European Neighborhood Policy as well as in the Energy Community. Similarly, in other regions, the EU follows the strategic goal of introducing market solutions in relations with the Russian Federation, countries from North Africa and Central Asia. Because these countries are not able to subordinate their energy markets to free market rules for various reasons, the EU Member States often return to classic foreign policy instruments and conclude bilateral agreements with important producers and transit countries (Pollak, Schubert, Slominski, 2010, pp. 145-146).

\section{Germany towards the external dimension of the EU's energy policy}

References to EU energy policy, including its external dimension, were included in the report on the national strategy in the oil and gas sector, adopted on 6th November 2008. In addition to the indication of actions taken by the EU so far in the context of the implementation of the "Action Plan for 2007-2009" discussed above, the following steps were enumerated in particular in the field of implementing the policy of "speaking with one voice" in the future:

- dialogues and partnerships, which should include elements of increasing energy efficiency and the development of alternative energy sources;

- closing the "energy" chapter within PCA with Russia based on the principles included in the Energy Charter Treaty;

- creating a single regulatory space by applying internal market rules in neighboring regions (e.g. extending the Energy Community to Ukraine, Moldova and Turkey) or by harmonizing rules (e.g. as part of the European Neighborhood Policy);

- continuation and intensification of dialogue with producers, consumers and transit countries through various instruments and fora;

- development of transmission infrastructure (with third countries [BM]). The federal government stressed that "bilateral infrastructure projects should be further planned and implemented by the right enterprises and countries." Ex-ante matching with all EU Member States and the European Commission would be against the principle of subsidiarity (Bundesregierung, 2008, pp. 50-51).

The demand to strengthen the external dimension of the EU's energy policy was reflected in the letter of Chancellor Angela Merkel and Prime Minister Donald Tusk to the President of the European Council Herman Van Rompuy and the President of the 
European Commission Jose Manuel Barroso quoted by the media at the beginning of February 2011. The letter published before the Summit emphasized the necessity of actions "in the spirit of solidarity and responsibility" and it was recalled that the diversification of supply sources and routes, including the construction of the Nabucco gas pipeline and the dissemination of market principles among EU partners based on the Energy Charter Treaty principles are "strong and coherent" goals of the EU's external energy policy. In this context, however, it was highlighted that EU Member States should retain the right to their own energy policy (Merkel, Tusk, 2011).

The federal government is in favour of diversifying sources and routes of supply, expanding dialogues with suppliers, transit countries and large energy consumers, supporting economic and scientific exchange, and ambitious targets for reducing greenhouse gas emissions, increasing energy efficiency and expanding renewable energy sources on the national, regional and international level. In the opinion of the federal government, diversification is the key to balancing energy supplies to the European Union at reasonable prices (Deutscher Bundestag, 2016a, p. 5; Deutscher Bundestag, 2017, p. 42). Hence, Germany supports the Southern Gas Corridor as compatible with the first pillar of the Energy Union, i.e. the diversification of EU gas supplies. ${ }^{2}$

The importance of the Southern Gas Corridor for EU energy security was emphasized by Chancellor Angela Merkel in August 2018 in Baku during a joint press conference with President Ilham Aliyev. The chancellor also confirmed the importance of Azerbaijan as a natural gas supplier - "the factor of diversification of energy supply to the EU" (Bundeskanzlerin, 2018a). In a similar vein, Merkel also spoke at a press conference on 21st January, 2015 in Berlin, underlining that the federal government "strongly supports the project of the Southern Gas Corridor", and "Azerbaijan is a partner of growing importance, partly due to the very dynamic development of the economy, [...] due to gas and oil resources [...]" (Bundeskanzlerin, 2015a).

It is estimated that the prospects for diversification of gas supply sources to Germany may best be served by the energy strategy of the European Union. This is supported by, firstly, the lack of the possibility of direct pipeline connection with potential natural gas suppliers with the exception of Russia; secondly, the inability to import liquefied natural gas, because Germany does not have its own regasification terminals for LNG. Therefore, the integration of gas transmission networks with infrastructure in the European Union would increase the German energy supply security. However, an efficiently functioning internal gas market would enable obtaining the raw material in an amount ensuring continuity and security of supply from many diversified sources.

In the context of the Energy Union, the federal government supports the EU's efforts to create a stable legal framework and market environment in the energy sector in Albania, Bosnia and Herzegovina, North Macedonia, Montenegro, Serbia, Kosovo, Ukraine and Moldova. In addition to strengthening the security of supply and expand-

${ }^{2}$ Parts of the Southern Gas Corridor are the Trans-Anatolian Pipeline (TANAP) and Trans Adriatic Pipeline (TAP) pipelines. The project implementation will allow the transport of natural gas from the Caspian region. TANAP, launched in 2018, runs through Turkey to the border with Greece, near the Turkish-Greek border is to be connected to TAP and transfer gas through Greece and Albania to Italy. Since 2020, 10 billion cubic meters natural gas annually from the Azeri Shah Deniz 2 fields are to be shipped via TANAP and TAP pipelines. 
ing relations with neighboring countries, the objectives of cooperation include improving energy efficiency and developing renewable energy sources as well as emphasizing environmental protection requirements when expanding the power grid. The federal government stands for extending the Energy Community to such countries as Norway, Georgia and Turkey. In addition, energy issues are the subject of the 2nd Platform of the Eastern Partnership of the EU, during which meetings with representatives of EU Member States and EaP countries (twice a year) take place. The thematic scope of the Platform includes energy security of partner countries, promotion of renewable energy sources and energy efficiency as well as nuclear safety. The issues of sustainable development and climate change (Panel on Environment and Climate Protection) also remain in the area of interest. The federal government participates in working sessions and Eastern Partnership meetings devoted to energy policy issues (Deutscher Bundestag, 2018).

For the countries of the Western Balkans and the EU's Eastern Partnership (Albania, Armenia, Azerbaijan, Belarus, Bosnia and Herzegovina, Georgia, Kosovo, North Macedonia, Moldova, Montenegro, Serbia, Ukraine) Germany is one of the main partners in bilateral cooperation and multilateral initiatives regarding energy and climate issues. The intention is to integrate energy markets in accordance with the goals of sustainable development, and thus to ensure security of supply and economic modernization in the region. The federal government supports the objectives of the Energy Community, in particular promoting energy transformation in the Member States. The regional project Capacity Development for climate policy in the countries of South East, Eastern Europe, the South Caucasus and Central Asia implemented as part of the International Climate Initiative (Internationale Klimaschutzinitiative) is therefore of great importance. The aim of the project is to integrate national climate protection objectives in development planning in the energy sector (development of national energy and climate plans) and to unify the evaluation of national contributions to climate protection with the objectives of the European Union (Deutscher Bundestag, 2018, pp. 1-3).

Finally, the federal government opts for emphasizing support for low-carbon technologies within the EU-US Energy Council (created in 2009). Additionaly, development of renewable energy sources and increasing energy efficiency are the subject of regular consultations with African, Asian and Latin American countries at the level of the EU. In this context, the federal government supports, particularly, cooperation in the field of environmental and climate protection. It includes consulting and financing investments in sustainable development of energy system (Deutscher Bundestag, 2017, p. 44).

\section{Directions and practice of German energy policy}

The need to intensify cooperation with producers, large energy consumers and transit countries has been defined as the goal of Germany's foreign policy as a consequence of the Russian-Ukrainian gas crisis of January 2006 (see: Geden, Marcelis, Maurer, 2006) and was reflected in later documents. Similarly, provisions regarding diplomatic support for export of innovations in the field of renewable energy sourc- 
es and energy efficiency were also included in the above mentioned documents. The aforementioned issues are raised during foreign visits of the Federal Chancellor and Federal Ministers (with the participation of representatives of the business), as part of bilateral intergovernmental consultations as well as in bilateral committees and working groups. The support provided to enterprises engaging in foreign energy projects by ministries, embassies or the foreign trade chamber as well as the guarantees of Hermes and UFK (Ungebundener Finanzkredit) is not without significance (Bundesregierung, 2008, pp. 38-39).

The importance of this matter can be demonstrated by its presence in the debate initiated in 2014 by the Federal Foreign Office (Auswärtiges Amt, AA) on the revision of the importance and responsibility of Germany's foreign policy in shaping peace and global security (Review, 2014) such questions as improving the security of energy supply and energy independence, developing dialogues with suppliers of fossil fuels, transit countries and energy consumers, developing renewable energy sources and increasing energy efficiency as well as encouraging the transfer of German know-how to partner countries (see: AA 2015).

Germany uses various forms of bilateral (and multilateral) cooperation with producers and transit countries important for security of energy supply in order to ensure stable conditions for implementation of diversification projects of sources and supply routes (they are an integral element of Germany's foreign policy with regard to Russia). It is also quintessential to back German companies in the field of exploration and production in the countries of natural gas and oil extraction and to woo producer countries for investments on the German energy market. Germany is also developing collaboration in the area of "clean energy technologies," energy efficiency and renewable energy sources, both with large energy consumers (China, India) and producers (Russia). In this case, it is also about the possibility of companies exporting energyefficient products and innovative energy installations.

The following models of ways to achieve the goals of Germany's energy policy can be distinguished (both internal and external):

a) reduction - measures to minimize dependence on fossil fuel imports (optimal use of own energy resources, the renewable energy development, increasing energy efficiency and promoting energy savings - energy transition, Energiewende);

b) diversification - supply sources and routs as well as ensuring continuity of supply (linking the issue of security of supply with deepening bilateral cooperation with the fossil fuel producing countries);

c) externalization - transferring experience of energy transition and export of technological solutions to partner countries in the sphere of renewable energy sources, energy saving and improving the energy efficiency. This applies to projects in the area of climate protection and development cooperation with the help of which German technological solutions employed in the process of energy transition can be shown.

Partnerships and energy dialogues are instruments by which the federal government shares the experiences of the energy transition process. Various formats such as business trips, exchange of experts, working groups and jointly organized events serve this purpose. The Federal Ministry for Economic Affairs and Energy (Bundesministerium für Wirtschaft und Energie, BMWi) is involved in energy part- 
nerships and dialogues, and the Federal Ministry for Economic Cooperation and Development (Bundesministerium für wirtschaftliche Zusammenarbeit und Entwicklung, BMZ) together with Federal Ministry for the Environment, Nature Conservation and Nuclear Safety (Bundesministerium für Umwelt, Naturschutz und Reaktorsicherheit, BMU) and the Federal Foreign Office are also involved in various ways. In the implementation of specific projects in partner countries, the federal government cooperates with intermediary organizations such as Gesellschaft für Internationale Zusammenarbeit (GIZ), Deutsche Energie-Agentur (dena), adelphi consult and Ecofys and the Chambers of Foreign Trade. According to the information contained in the report published by BMWi in March 2018, energy partnerships were concluded with Algeria, Australia, Brazil, China, India, Morocco, Mexico, South Africa, Tunisia, Turkey and the United Arab Emirates (UAE). On the other hand, energy dialogues are conducted with Iran, Japan, Kazakhstan, Russia, South Korea, Ukraine and the USA (also with California and New York). Apart from that, BMWi cooperates with Jordan, Belarus and Egypt too. The task of BMZ and BMU is to help partner countries to create appropriate conditions for sustainable energy supply and implementation of national strategies. Emphasis is placed on promoting low-carbon energy technologies and energy efficiency. The liberalization of the electricity market (in Mexico), power plants and hard coal extraction modernization, electricity transmission networks, electricity and gas market regulation (in Turkey), electromobility and sustainable transport (in the UAE) are significant issues as well (BMWi, 2018);

d) consolidation - consolidation of existing energy partnerships and dialogues (such as with Russia), by gradually incorporating new matters related to the development of "clean energy."

Based on the above models (b-d), the practice of Germany's energy policy will be briefly discussed in relation to countries with which energy partnerships and dialogues are maintained.

Energy cooperation between Germany and Brazil was initiated together with the 1975 agreement on the peaceful use of nuclear energy. Currently, renewable energy sources and energy efficiency occupy a central place within the energy partnership. Two working groups are a forum for discussions on renewable energy sources, including bioenergy, and energy efficiency. The basis for cooperation in the area of energy and climate are agreements, including the German-Brazilian Energy Agreement (2008), the German-Brazilian Memorandum on Climate Change (2009), the Brazilian-German Committee on Climate Change, the Cooperation for Sustainable Development, and the Brazilian-German Joint Statement on Climate Change signed shortly before the Paris Climate Conference in 2015. This last document among others emphasizes cooperation in the area of low-carbon development and promotion of the use of energy from renewable sources. During the first bilateral intergovernmental consultations in 2015 the interested parties agreed to intensify energy cooperation. At the same time, the potential of cooperation in the field of research, development and innovation in areas such as biofuels, solar energy, energy efficiency and Clean Development Mechanism (CDM) was emphasized (Bundeskanzlerin, 2015b). After 2008, when the energy partnership was initiated, the contentious issues blocked dialogue in the field of renewable 
energy sources (see: Röhrkasten, 2015). In the view of the Brazilian government, the German requirements for the production of ethanol fuel were aimed mainly at protecting the domestic biofuel sector from competition from Brazil. In turn, Germany wanted to promote solar and wind energy, so those sources which use is important in the process of energy transition (Knodt, Chaban, Nielsen, 2017, p. 117).

Mexico is one of the major consumer with a high proportion of energy consumption in the transport and industry sectors. Energy consumption is strongly influenced by fossil fuels. Mexico, like Germany, aims at a comprehensive reconstruction of the energy system, and thus improvement of energy efficiency and increase in the the use of renewable energy sources. This is the main reason for which Germany commited to developing energy cooperation with Mexico. On 12nd March, 2016 Joint Declaration of Intent on the Energy Partnership between Germany nad Mexico was signed. "The Energy Partnership is a high-level political and strategic exchange of information and best practices between the competent authorities, regulatory bodies, energy system operators and other relevant actors, with a special focus on the involvement of actors from the private sector" (BMWi, 2016a). The participants intend to concentrate their cooperation and political dialogue i.a. on the following areas: deployment and development of renewable energy technologies, development of electricity and gas markets, improvement and promotion of energy efficiency, urban smart mobility cooperation on transparency and accountability in the oil and gas extracting industries, clean fuel production. The German-Mexican Energy Partnership was initiated in June 2016. High-Level Steering Group of the above-mentioned forum met for the second time in September 2017. At that point, Rainer Baake and his counterparts, Hernández and Beltrán, decided to work together on a range of issues: liberalizing electricity markets, integrating variable renewables into electricity grids, energy efficiency in industry, and reducing inefficientsubsidies for fossil fuels both at domestic and international levels (BMWi, 2017a). The activities are closely linked to the work on energy of the Working Group on Economic Affairs and Energy and are in line with the actions of the Working Group on Sustainable Development, Environment and Climate Change of the Binational Commission for a German-Mexican Alliance for the Future.

Australia is another of the countries with which Germany has been initiating and intensifying cooperation in the area of energy in recent years. During the Berlin Energy Transition Dialogue in March 2017, a declaration of intent on the cooperation between federal governments of Germany and Australia in the field of energy and raw materials was signed. The created bilateral working group on energy and raw materials is concentrated on the exchange of information on long-term energy strategies in both countries to promote and accelerate the transition to environmentally sound and affordable energy supply (BMWi, 2017b). Through regular exchange of experiences and good practices, both governments strive to increase energy efficiency, endorse the development of renewable energy sources, create stable conditions for investment and increase security of supply through the diversification of energy sources.

In the second decade of the 21 st century Germany strengthened collaboration with large energy consumers - China and India - in the area of climate protection and sustainable energy.

Fossil fuels have a significant share in the structure of primary energy consumption in India, while the share of coal in energy consumption is $58 \%$ and $70 \%$ of the power 
plant is coal-fired. The Indo-German Energy Forum (Deutsch-Indisches Energieforum) was created in 2006 by Prime Minister Manmohan Singh and Chancellor Angela Merkel to develop cooperation in the areas of energy security, energy efficiency, renewable energy and investments in energy projects. As early as in 2003, the IndoGerman Energy Program (Deutsch-Indisches Energieprogramm) was initiated, which supported the implementation of the 2001 Indian Energy Conservation Act (Knodt, Chaban, Nielsen, 2017, p. 191).

The Joint Statement on Climate Change and Energy Technology Cooperation from October 2015 announced the intensification of cooperation in the development of climate-friendly solutions for India's growing energy needs (Bundesregierung, 2015). Both countries welcomed the letter of intent on bilateral partnership for solar energy, which is based on loans granted on preferential terms of EUR 1 billion over five years. Prime Minister Narendra Modi and Chancellor Angela Merkel have decided to create an Indo-German Climate and Renewable Alliance i.e. a comprehensive partnership to use technology and innovation, to provide everyone with "clean" and affordable energy, and to support efforts to alleviate effects of climate change in both countries. Under this form of cooperation it is possible to establish tripartite aid programs involving co-action between India and Germany to meet the development challenges of solar energy in third countries. In May 2017, Prime Minister Narendra Modi met with Chancellor Merkel during the Indo-German intergovernmental consultations in Berlin. During the talks, the role of the energy forum for the transformation of energy systems in both countries was accented as well as the success of the partnership in the field of solar energy and the development of the transmission network (Bundesregierung, 2017).

China is one of the world's largest importers of energy resources and is highly reliant on external supplies. China is also the world's largest emitter of greenhouse gases. The energy partnership between Germany and China existing since 2006 has been intensified since 2013, when two cooperation agreements in the area of energy saving and increasing energy efficiency were concluded along with deepening cooperation in the sphere of renewable energy sources. The federal government encourages many projects related to climate protection, including advice on introducing a system of emission allowance trading and development of low-emission transport systems. The energy partnership is aimed at disseminating the experiences of the German energy transition and showing the Chinese energy industry challenges on the path to a low-emission economy. Regular meetings of working groups and high-level bilateral meetings facilitate an intensive political and technical dialogue on energy transition. Germany and China collaborate in the liberalization of the electricity market, dissemination of efficient energy technologies and development and integration of renewable energy in transmission networks. These issues seem to be a new impulse for long-term relations between Germany and China.

In the Joint Declaration from the fourth German-Chinese intergovernmental consultations in 2016, intensified cooperation was announced in areas such as energy law, renewable energy sources and smart grids as well as energy efficiency and electromobility (Bundeskanzlerin, 2016). The declaration on cooperation in the field of sustainable mobility, energy efficiency and emission reduction along with modern transport 
technologies was signed with the Chinese Ministry of Science and Technology (BMVBS, currently Bundesministerium für Verkehr und digitale Infrastruktur, BMVI). The Ministry of Agriculture of both countries signed a letter of intent regarding cooperation in the field of biogas.

Due to its geographical location and political contacts in the region, Turkey, as a transit country and a negotiating partner with producers natural gas, appeared an important partner for the EU and Germany. Moreover, from Germany's perspective, an instrumental premise for developing cooperation with Turkey was the intention of German companies to become more involved in energy projects on that market. On 15th November, 2012, joint declaration on energy cooperation was signed by the ministers of Germany and Turkey (BMWi, 2012c), and in 2013 the first meeting of the German-Turkish Energy Forum was held (the second took place only in 2018). The joint declaration provided for the creation of five working groups: 1. renewable energy sources; 2 . energy efficiency; 3 . conventional power plants, power plant modernization, lignite mining; 4 . distribution of electricity and transmission networks; 5 . regulation of the electricity and gas market, establishing of an electricity and gas exchange, consumer interests. What is more, it was important to have intensified efforts to harmonize Turkey's energy law with the EU. Germany and Turkey plan new energy projects and want to intensify cooperation in the energy sector. A relevant letter of intent in this matter was signed by the Federal Minister for Economic Affairs and Energy, Peter Altmaier, and the Turkish Minister of Industry, Fatih Dönmez, in October 2018 in Ankara (Reuters, 2018).

The United Arab Emirates is one of the leading oil producers; they also aspire to the role of a leader in the field of low-emission technologies. On 16th January 2017, a joint declaration of intent on cooperation in the fields of energy between Germany and the UAE was signed. The work program for the first year of the energy partnership included scientific exchanges, workshops, industry meetings and visits from delegations from both countries. To tighten cooperation in the energy sector, Germany and the UAE plan to cooperate in the framework conditions for technologies in the sphere of renewable energy, energy efficiency, development of electricity markets and research and development (BMWi, 2017c). In accordance with paragraph 1 of the above document, the parties agree on the common goal of a thorough change of energy systems, promoting energy efficiency and renewable energy sources to achieve the objectives of the 2015 Paris Agreement. Collaboration with the UAE through the energy partnership started in early 2017 in the area of renewable energy sources and energy efficiency, can contribute to energy transformation in the MENA region.

The second decade of the 21st century is Germany's activity in the field of developing energy partnerships with Morocco, Tunisia, Algeria and South Africa.

The federal government supports Morocco in implementing its ambitious plans to develop renewable energy sources and reduce greenhouse gas emissions. Morocco, on the one hand, depends on the import of fossil fuels for electricity production, on the other hand, it has excellent geographical conditions for generating electricity from the sun (and wind) and a relatively well-developed power system. On 3rd July 2012, Philipp Rösler, Federal Minister for Econimic Affairs and Technology and Moroccan Minister of Energy, Mining, Water and the Environment, Fouad Douiri, signed a joint 
declaration of intent regarding the energy partnership (Gemeinsame Absichtserklärung über die Einrichtung einer Energiepartnerschaft zwischen dem Königreich Marokko und der Bundesrepublik Deutschland) (BMWi, 2012b). The energy partnership is managed by High-Level Steering Committee composed of representatives of the relevant ministries and the chairmen of the working groups. The Committee was obliged to submit an annual report on the progress of the implementation process of the assumptions and objectives of the partnership. Initially, thematic working groups were established: renewable energy sources, the Desertec project and sustainable development. In a short time, the fourth working group "power grids" was formed, in which the emphasis is placed on the integration of renewable energy sources with the network in Morocco (Deutscher Bundestag, 2017b, p. 3; Deutscher Bundestag, 2016c, p. 11). The essence of the energy partnership is supporting the development of renewable energy sources, improving energy efficiency and energy saving as well as the development of power grids and energy research. Morocco can benefit from the experience of German enterprises and technological solutions, especially in the area of renewable energy. On 19th April, 2016, the Memorandum of Understanding was signed, under which the countries agreed to cooperate on the use of sustainable energy by 2050 .

At the beginning of 2013, the energy partnership with Tunisia was officially launched. Its basis is the Joint Declaration of Intent signed on 9th January, 2012. The aim is to enhance the framework conditions for cooperation between the two countries in the following spheres: reduction of energy consumption, improving energy efficiency, renewable energy sources and reduction of greenhouse gas emissions. Three working groups are currently acting on the topics of energy policy, low-emission strategies and green economy. Tightening bilateral energy cooperation will be served, among others, by mutual exchange of experience and information, including on financing specific ventures, political support for investment projects of German enterprises in Tunisia and partnerships between institutions, universities and scientists. State Secretary at the Federal Ministry for Economic Affairs and Energy, Rainer Baake, emphasized during the meetings of the High-Level Steering Committee that German-Tunisian Energy Partnership is an institutionalized energy policy dialogue to accompany Tunisia in the development and implementation of the national energy policy - in favour of a sustainable energy supply (BMWi, 2015; BMWi, 2016b).

The energy partnership with Algeria was created in 2015. Renewable energy sources in Algeria, despite their potential, currently have a small share in energy production. Energy needs are met almost exclusively by domestic fossil fuels. Two working groups handle with issues of renewable energy sources and energy efficiency. Algeria uses the experience of the German energy transition to develop and implement an energy policy for a sustainable energy supply. During a joint press conference with Prime Minister Ahmed Ouyahia in September 2018 in Algiers, Merkel stressed that Germany wants to contribute to the diversification of the Algerian economy while referring to the energy partnership (Bundesregierung, 2018).

Coal is the pillar of South Africa's energy supply with $68.4 \%$ share in energy consumed (2015), while the share of solar, wind and nuclear energy is - respectively $1 \%$ and $1.9 \%$. South Africa is responsible for $1 / 3$ of greenhouse gas emissions in Africa. Important goals of the South Africa's energy policy are energy efficiency, a reliable 
energy supply, job creation and an increasing share of renewable energies in power generation. South Africa is an interesting market for German companies from the renewable energy sector, especially wind and solar energy. On 21st February, 2013, Joint Declaration of Intent on the Establisment of an Energy Partnership was signed. The main objectives of the partnership include the development of renewable energy sources and power grids, improving energy efficiency and development of energy research as well as cooperation in the field of carbon capture and storage (CCS) (BMWi, 2013). The government of South Africa wants to attract potential investors to expand energy infrastructure and benefit from Germany's experience in key energy questions.

Energy dialogues are developed with three countries of the post-Soviet space - Russia (the main supplier of energy resources to Germany), Ukraine (a transit country of energy resources) and Kazakhstan (Germany's fourth-biggest oil supplier).

Germany is a recipient of Russian energy resources - natural gas and crude oil (to a lesser extent coal), as well as a transit country, a distributor and an end customer. Russia has effectively sought to gain access to the gas transmission and storage infrastructure in Germany. In 2000, a Russian-German Working Group on Strategic Economic and Financial Cooperation (Deutsch-Russische Strategische Arbeitsgruppe für Wirtschaft und Finanzen) was established, which was to deal with specific projects, including in the energy sector. Furthermore, the German-Russian Energy Forum (Deutsch-Russisches Energieforum) is a bilateral cooperation instrument. At the beginning of the 21 st century, energy cooperation between Germany and Russia was extended to include energy efficiency issues and the development of renewable energy sources. For example, in October 2016, the federal government supported the conference on renewable energy sources held in Russia (REENCON-XXI). The German embassy in Moscow was involved in the preparation of the conference, and representatives of the Federal Affairs Office and the Federal Ministry for Economic Affairs and Energy took part in it (Deutscher Bundestag, 2017, p. 53). Actions are taken to strengthen energy collaboration with the Russian Federation, and support for the Nord Stream 2 project has been expressed many times in official German-Russian political relations. Moreover, in the context of the conflict in the East of Ukraine and the annexation of Crimea as well as EU sanctions against Russia, there were questions about their impact on German-Russian energy cooperation, as well as security of supply. It was accentuated that if this does not apply to sanctions, companies decide on the degree of involvement in the Russian energy sector or energy trade with Russia. What is more, the federal government has not recorded a weakening of the level of security of supply in Germany. In the foreseeable future Russia will remain a supplier of energy resources of key importance to Germany and the EU as a whole (Deutscher Bundestag, 2017, p. 52).

Ukraine is dependent on the import of energy resources, nevertheless it has favorable conditions for the development of renewable energy sources. The Export Energy Initiative (Exportinitiative Energie) of the Federal Ministry for Economic Affairs and Energy supports the development of energy from renewable sources in this country. In the second quarter of 2019 a German delegation is planned to travel to Ukraine as part of an export initiative which subject is energy efficiency and renewable energy in buildings with focus on solar energy (Deutscher Bundestag, 2018, p. 14). Ukraine, as 
a transit country for gas transmitted from Russia to the West, is against the realization of the Nord Stream 2 project. During the Third German-Ukrainian Economic Forum on 29th November, 2018 in Berlin, Chancellor Merkel noted that Nord Stream 1 did not lead to the cut-off of Ukraine from supplies of the Russian raw material, and at the same time assured that Ukraine will continue to be an important transit country. At the same time, she expressed hope that talks about a new transit agreement would soon be initiated (the existing agreement expires in 2019) and confirmed the will to include Germany in the negotiation of this agreement (Bundeskanzlerin, 2018b).

Kazakhstan is a partner not only for the supply of oil to Germany, but also for potential in the area of energy efficiency and renewable energy sources. The first talks on the partnership agreement were conducted under the direction of BMWi in April 2011 in Astana. On the 24th May, 2011 a declaration of intent was signed, and on 8th February, 2012 a partnership agreement in the "sphere of raw materials, industry and technology" was concluded too. On its basis, German enterprises could seek and extract, among others rare earth metals in Kazakhstan. On top of that, Germany was to support, among others technology transfer to Kazakhstan (BMWi, 2011a; BMWi, 2011b; BMWi, 2012a). Cooperation with Kazakhstan focuses principally on increasing the efficiency of the employment of raw materials and resources, implementing environmental protection standards in obtaining and processing of raw materials. The bilateral Working Group Economy and Trade (Deutsch-Kasachische Regierungsarbeitsgruppe Wirtschaft und Handel) the main forum for economic cooperation at the governmental level (Deutscher Bundestag, 2016b).

In addition, Germany has initiated and is developing an energy dialogue with Iran. In October 2016, during the 5th meeting of the German-Iranian Joint Economic Commission, it was agreed to establish a bilateral energy dialogue aimed at supporting Iran in the modernization of energy infrastructure. The development of renewable energy sources and the improving energy efficiency will be of significance (BMWi, 2016c).

In turn, the energy dialogue between Germany and the US focuses on the potential and challenges of energy transition, the exchange of experience in the design of electricity markets, security of supply and network stability, and last but not least, the integration of renewable energy sources in power networks. On the other hand, South Korea, like Germany, increases the employment of renewable energy sources, at the same time withdrawing from the usage of nuclear energy and reducing its dependence on fossil fuels. Therefore, the foremost subject of interest within the framework of the bilateral energy dialogue are matters related to the development of alternative energy sources.

The creation of a stable energy mix forced inclusion of the issue of development of renewable energy sources and energy efficiency into the Japan's energy policy. It puts it in front of challenges similar to what Germany is confronted with in the process of energy transition, i.e. the extension and modernization of energy infrastructure, the digitization of the energy sector and the integration of renewable energy sources into the grids. The subject of the 9th German-Japanese Environment and Energy Dialogue Forum, which took place on 19th/20th April, 2018 in Berlin, focused on low-carbon transport systems and the possibilities of effective use of renewable energy sources in the transport sector. The German-Japanese Environment and Energy Dialogue Forum 
(established in 2007) has become a leading platform for the exchange of experiences in the field of environmental and climate protection and energy as well as the initiation of German-Japanese projects (DJW, 2018).

\section{Conclusion}

The EU's external energy policy is essentially a deepening of political relations with producer and transit countries of energy raw materials as well as consumers, and its practical dimension is the implementation of specific projects. The agreements concluded and tailored to individual partners were primarily aimed at establishing cooperation priorities and setting desirable directions of activities of the EU institutions as well as the Member States. In addition to bilateral projects, in relations with third countries they are used instruments such as the Energy Charter Treaty, which creates uniform rules for EU multilateral energy cooperation, and the Energy Community, under which non-EU countries have been required to implement specific EU legal acts.

The effectiveness of the external dimension of the EU's energy policy is conditioned by consensus between Member States which attainment is hampered by the existence of diverse positions as to the directions and forms of external energy policy. Frequently different approaches to the external dimension of the EU's energy policy resulted from geographical and historical conditions, own resources and needs as well as relations of EU Member States with producers and transit countries for energy resources. Moreover, the challenge for the effectiveness of the external dimension of the EU's energy policy is the lack of a clear definition (provisions of the Lisbon Treaty) of the competences of individual EU institutions in this field.

Germany supports the expansion of EU relations with third countries based on the necessity of geographical diversification of sources and transit routes (e.g. Southern Gas Corridor), as well as establishing and developing cooperation with large consumers of energy raw materials in the context of achieving the goal of the EU's influence on development directions energy situation on a global scale. However, unlike the EU institutions, Germany perceived relations with the Russian Federation especially in the context of the Nord Stream 2 project.

The goal of Germany's policy is to maintain good relations with key partners on the energy market, both producers, transit countries and consumers of energy raw materials, enabling the realization of German interests. Therefore, various instruments and mechanisms of bilateral cooperation are used, and new forms of cooperation with new partners are developed, which is in line with the general objectives of promoting renewable energy sources and gaining market outlets for modern energy technologies.

\section{Biblography}

AA (2015), Krise - Ordnung - Europa. Review 2014: Außenpolitik Weiter Denken, Berlin, http:// www.auswaertigesamt.de/cae/servlet/contentblob/699336/publicationFile/202955/Review_ Abschlussbericht.pdf, 22.05.2019. 
BMWi (2018), Jahresbericht 2017, Energiepartnerschaften, März 2018, https://www.bmwi. de/Redaktion/DE/Publikationen/Energie/jahresbericht-energiepartnerschaften.pdf? blob=publicationFile\&v=13, 29.10.2018.

BMWi (2017c), Energiepolitische Zusammenarbeit zwischen Deutschland und den Vereinigten Arabischen Emiraten, 16.01.2017, https:/www.bmwi.de/Redaktion/DE/Pressemitteilungen/2017/20170116-energiepolitische-zusammenarbeit-zwischen-deutschlandund-arabischen-emiraten.html, 30.05.2019.

BMWi (2017b), Deutschland und Australien gründen eine bilaterale Arbeitsgruppe zu Energie und Rohstoffen, 21.03.2017, Pressemitteilung, https://www.bmwi.de/Redaktion/DE/ Pressemitteilungen/2017/20170321-deutschland-australien-gruenden-bilaterale-arbeitsgruppe-zu-energie-und-rohstoffen.html, 30.05.2019.

BMWi (2017a), Globale Energiewende schreitet voran. Deutschland vertieft Kooperation mit Mexiko, 13.09.2017, Pressemitteilung, https:/www.bmwi.de/Redaktion/ DE/Pressemitteilungen/2017/20170913-globale-energiewende-schreitet-voran.html, 25.05.2019.

BMWi (2016c), Gabriel reist mit Wirtschaftsdelegation in den Iran und eröffnet die 5. Sitzung der Deutsch-Iranischen Gemischten Wirtschaftskommission, 02.10.2016, Pressemitteilung, https://www.bmwi.de/Redaktion/DE/Pressemitteilungen/2016/20161002-gabriel-reist-mitwirtschaftsdelegation-in-den-iran-und-eroeffnet-die-5-sitzung-der-deutsch-iranischen-gemischten-wirtschaftskommission.html, 30.05.2019.

BMWi(2016b), Staatssekretär Baake empfängtden tunesischen Energieminister Marzoug, 11.07.2016, Pressemitteilung, https://www.bmwi.de/Redaktion/DE/Pressemitteilungen/2016/20160711staatssekretaer-baake-empfaengt-den-tunesischen-energieminister-marzoug.html, 30.05.2019.

BMWi (2016a), Joint Declaration of Intent on the Energy Partnershipbetweenthe Government of the United Mexican Statesandthe Government of the Federal Republic of Germany, https:// www.bmwi.de/Redaktion/EN/Downloads/gemeinsame-erklaerung-mexiko-deutschlandenergiepartnerschaft-englisch.pdf?_blob=publicationFile\&v=3, 25.05.2019.

BMWi (2015), Energiewende in Tunesien - Staatssekretär Baake reist zur Sitzung der Deutsch-Tunesischen Energiepartnerschaft nach Tunis, 15.12.2015, Pressemitteilung, https://www.bmwi. de/Redaktion/DE/Pressemitteilungen/2015/20151215-baake-reise-tunis.html, 30.05.2019.

BMWi (2013), Bundesregierung begründet deutsch-südafrikanische Energiepartnerschaft, 21.02.2013, Pressemitteilung, http://www.bmwi.de/DE/Presse/Pressemitteilungen/pressemitteilungenarchiv,did=552820.html, 25.05.2019.

BMWi (2012c), Gemeinsame Erklärung zwischen dem Bundesministerium für Wirtschaft und Technologie der Bundesrepublik Deutschland und dem Ministerium für natürliche Energie und natürliche Ressourcen der Republik Türkei zur Zusammenarbeit im Energiebereich, 15.11.2012, https://www.bmwi.de/Redaktion/DE/Downloads/G/gemeinsame-erklaerungdeutschland-tuerkei-energiepartnerschaft.html, 30.05.2019.

BMWi (2012b), Gemeinsame Absichtserklärung über die Errichtung einer Energiepartnerschaft zwischen dem Königreich Marokko und der Bundesrepublik Deutschland, https://www. bmwi.de/Redaktion/DE/Downloads/G/gemeinsame-erklaerung-deutschland-marokko-energiepartnerschaft.pdf?_blob=publicationFile\&v=3, 25.05.2019.

BMWi (2012a), Rohstoffpartnerschaft mit Kasachstan unterzeichnet, 08.02.2012, Pressemitteilung, http://www.bmwi.de/DE/Presse/pressemitteilungen,did=474650.html, 29.05.2019.

BMWi (2011b), Wirtschaftsministerium schließt Memorandum of Understanding für Rohstoffpartnerschaft mit Kasachstan ab, 24.05.2011, Pressemitteilung, http://www.bmwi.de/DE/Presse/ pressemitteilungen, did=391262.html, 29.05.2019.

BMWi (2011a), Rohstoffpartnerschaft mit Kasachstan auf gutem Weg, 14.04.2011, Pressemitteilung, http://www.bmwi.de/DE/Presse/pressemitteilungen,did=386550.html, 29.05.2019. 
Bundeskanzlerin (2018b), Rede von Bundeskanzlerin Merkel beim 3. Deutsch-Ukrainischen Wirtschaftsforum am 29. November 2018 in Berlin, https://www.bundeskanzlerin. de/bkin-de/aktuelles/rede-von-bundeskanzlerin-merkel-beim-3-deutsch-ukrainischenwirtschaftsforum-am-29-november-2018-in-berlin-1555732, 29.05.2019.

Bundeskanzlerin (2018a), Pressekonferenz von Bundeskanzlerin Merkel und Präsident Ilham Alijew, in Baku, 25. August 2018, https://www.bundeskanzlerin.de/bkin-de/aktuelles/pressekonferenz-von-bundeskanzlerin-merkel-und-praesident-ilham-alijew-1504726, 20.052019)

Bundeskaznlerin (2016), Gemeinsame Erklärung anlässlich der 4. Deutsch-Chinesischen Regierungskonsultationen, 13. Juni 2016, https://www.bundeskanzlerin.de/Content/DE/Pressemitteilungen/BPA/2016/06/2016-06-13-regierungskonsultationen.html, 29.05.2019.

Bundeskanzlerin (2015b), Gemeinsame Erklärung anlässlich der Ersten Hochrangigen DeutschBrasilianischen Regierungskonsultationen, 19.-20. August 2015, https://www.bundeskanzlerin.de/Content/DE/Artikel/2015/08/2015-08-20-abschlusserklaerung-brasilien.html, 29.10.2018.

Bundeskanzlerin (2015a), Pressekonferenz von Bundeskanzlerin Merkel und dem Präsidenten der Republik Aserbaidschan, Ilham Alijew in Berlin, 21. Januar 2015, https://www.bundeskanzlerin.de/bkin-de/aktuelles/pressekonferenz-von-bundeskanzlerin-merkel-und-dem-praesidenten-der-republik-aserbaidschan-ilham-alijew-844610, 20.05.2019.

Bundesregierung (2018), Pressekonferenz von Bundeskanzlerin Merkel und dem algerischen Premierminister Ahmed Ouyahia in Algier, 17. September 2018, https://www.bundesregierung. de/breg-de/suche/pressekonferenz-von-bundeskanzlerin-merkel-und-dem-algerischen-premierminister-ahmed-ouyahia-1523382, 30.05.2019.

Bundesregierung (2017), Pressekonferenz von Bundeskanzlerin Merkel und dem indischen Premierminister Narendra Modi im Bundeskanzleramt, 30. Mai 2017, https://www.bundesregierung. de/breg-de/aktuelles/pressekonferenzen/pressekonferenz-von-bundeskanzlerin-merkel-unddem-indischen-premierminister-narendra-modi-844880, 29.05. 2019.

Bundesregierung (2105), Indo-German Joint Statement on Climate Change and Energy Technology Cooperation, The Press and Information Office of the Federal Government, October 05, 2015, https://archiv.bundesregierung.de/archiv-de/meta/startseite/indo-german-jointstatement-on-climate-change-and-energy-technology-cooperation-605406, 29.05.2019.

Bundesregierung (2008), Bericht der Bundesregierung zur Öl- und Gasmarktstrategie, http://docplayer.org/3852318-Bericht-der-bundesregierung-zur-oel-und-gasmarktstrategie.html, 16.05.2019.

Commission of the European Communities (2008), Communication from the Commission to the European Parliament, the Council, the European Economic and Social Committee and the Committee of the Regions, Second Strategic Energy Review. An EU Energy Security and Solidarity Action Plan, COM(2008) 781 final, Brussels, 13.11.2008, https://eur-lex.europa.eu/ LexUriServ/LexUriServ.do?uri=COM:2008:0781:FIN:EN:PDF, 20.05.2019.

Commission of the European Communities (2007), Communication from the Commission to the European Council and the European Parliament - An energy policy for Europe, $\mathrm{COM(2007)}$ 1 final, Brussels, 10.1.2007, https://eur-lex.europa.eu/legal-content/EN/TXT/PDF/?uri= CELEX:52007DC0001\&from=EN, 19.05.2019.

CommissionoftheEuropeanCommunities(2006b), Communicationfrom the CommissiontotheEuropean Council, Externalenergyrelations-fromprinciplestoaction, COM(2006)590final,Brussels, 12.10.2006, https://www.eumonitor.eu/9353000/1/j4nvke1fm2yd1u0_j9vvik7m1c3gyxp/ vkcweehnfzzs/v=s7z/f=/com(2006)590_en.pdf, 20.05.2019.

Commission of the European Communities (2006a), Green Paper: A European strategy for sustainable, competitive and secure energy, $\operatorname{COM}(2006) 105$ final, Brussels, 08.03.2006, https:// eur-lex.europa.eu/legal-content/EN/TXT/?uri=celex:52006DC0105, 15.05.2019. 
Commission of the European Communities (2003), Communication from the Commission to the Council and the European Parliament on the Development of energy policy for the Enlarged European Union, its Neighbours and Partner Countries, COM(2003) 262 final, Brussels, 21.05.2003, http://ec.europa.eu/transparency/regdoc/rep/1/2003/EN/1-2003-262-EN-F1-1. Pdf, 16.05.2019.

Commission of the European Communities (2000), Green Paper, Towards a European strategy for the security of energy supply, COM/2000/0769 final, Brussels, 29.11.2000, https://eur-lex.europa.eu/legal-content/EN/TXT/HTML/?uri=CELEX:52000DC0769\&from=EN, 15.05.2019.

Commission/SG/HR for the European Council (2006), An External Policy to serve Europe's Interests, S160/06, https://www.consilium.europa.eu/ueDocs/cms_Data/docs/pressData/en/ reports/90082.pdf, 17.05.2019).

Council of the European Union (2017), Implementing the EU Global Strategy - strengthening synergies between EU climate and energy diplomacies and elements for priorities for 2017, Council conclusions (6 March 2017), http://data.consilium.europa.eu/doc/document/ST6981-2017-INIT/en/pdf, 28.05.20190.

Council of the European Union (2011b), Council conclusions on strengthening the external dimension of the EU energy policy, 3127th Transport, Telecommunications and Energy Council meeting (Energy items) Brussels, 24 November 2011, https:/www.consilium.europa.eu/ uedocs/cms_data/docs/pressdata/en/trans/126327.pdf, 25.05.2019.

Council of the European Union (2011a), Presidency Conclusions, European Council $4^{\text {th }}$ February 2011, https://ec.europa.eu/research/era/docs/en/brussels-european-council-4february-2011-presidency-conclusions.pdf, 22.05.2019.

Council of the European Union (2009), Presidency Conclusions, European Council 19/20 March 2009, https://www.consilium.europa.eu/uedocs/cms_data/docs/pressdata/en/ec/106809.pdf, 20.05.2019.

Council of the European Union (2007), Presidency Conclusions, European Council 8/9 March 2007, http://register.consilium.europa.eu/doc/srv?l=EN\&f=ST\%207224\%202007\%20REV\%201, 19.05.2019.

Council of the European Union (2006), Presidency Conclusions, European Council 23/24 March 2006, https://www.consilium.europa.eu/ueDocs/cms_Data/docs/pressData/en/ec/89013.pdf, 16.05.2019.

Deutscher Bundestag (2018), Antwort der Bundesregierung auf die Kleine Anfrage der Abgeordneten Manuel Sarrazin, Jürgen Trittin, Lisa Badum, weiterer Abgeordneter und der Fraktion Bündnis 90/Die Grünen, Klimaschutz- und Energieaußenpolitik in Bezug auf die Länder des Westlichen Balkans und der Östlichen Partnerschaft, Drucksache 19/5772, 13.11.2018.

Deutscher Bundestag (2017b), Antwort der Bundesregierung auf die Kleine Anfrage der Abgeordneten Eva Bulling-Schröter, Caren Lay, Annette Groth, weiterer Abgeordneter und der Fraktion DIE LINKE, Beteiligung am größten Solarthermie-Kraftwerk der Erde in Ouarzazate, Marokko, Drucksache 18/10926, 20.01.2017.

Deutscher Bundestag (2017), Antwort der Bundesregierung auf die Große Anfrage der Abgeordneten Jürgen Trittin, Dr. Frithjof Schmidt, Oliver Krischer, weiterer Abgeordneter und der Fraktion BÜNDNIS 90/DIE GRÜNEN, Schlüssel für eine globale, ökologische und gerechte Energieaußenpolitik, Drucksache 18/11694, 27.03.2017.

Deutscher Bundestag (2016c), Antwort der Bundesregierung auf die Kleine Anfrage der Abgeordneten Annalena Baerbock, Uwe Kekeritz, Bärbel Höhn, weiterer Abgeordneter und der Fraktion Bündnis 90/Die Grünen, Finanzierung des internationalen Klimaschutzes, Drucksache 18/10685, 15.12.2016.

Deutscher Bundestag (2016b), Antwort der Bundesregierung auf die Kleine Anfrage der Abgeordneten Wolfgang Gehrcke, Annette Groth, Dr. André Hahn, weiterer Abgeordneter und 
der Fraktion Die Linke, Die deutschen Beziehungen zu Kasachstan, Drucksache 18/7016, 20.01.2016.

Deutscher Bundestag (2016a), Antwort der Bundesregierung auf die Kleine Anfrage der Abgeordneten Jürgen Trittin, Annalena Baerbock, Oliver Krischer, weiterer Abgeordneter und der Fraktion Bündnis 90/Die Grünen, Auswirkungen und Risiken des Südlichen Gaskorridors, Drucksache 18/9113, 07.07.2016.

DJW (2018), 9. Deutsch-Japanisches Umwelt- und Energiedialogforum, https://www.djw.de/de/ veranstaltungen/weitere-veranstaltungen/9-deutsch-japanisches-umwelt-und-energiedialogforum, 30.05.2019.

ESS (2003), Ein sicheres Europa in einer besseren Welt. Europaeische Sicherheitsstrategie, Brüssel, 12. Dezember 2003, http://www.mombaur.de/pdf/031208ESSIIDE.pdf, 15.05.2019.

European Commission (2015), Energy Union Package. Communication from the Commission to the European Parliament, the Council, the European Economic and Social Committee, the Committee of the Regions and the European Investment Bank, A Framework Strategy for a Resilient Energy Union with a Forward-Looking Climate Change Policy, COM(2015) 80 final, Brussels, 25.02.2015, https://eur-lex.europa.eu/resource.html?uri=cellar:1bd46c90bdd4-11e4-bbe1-01aa75ed71a1.0001.03/DOC_1\&format=PDF, 26.05.2019.

European Commission (2013), Report from the Commission to the European Parliament, the Council and the European Economic and Social Committee, Implementation of the Communication on Security of Energy Supply and International Cooperation and of the Energy Council Conclusions of November 2011, $\operatorname{COM(2013)~} 638$ final, Brussels, 13.09.2013, https://eur-lex. europa.eu/LexUriServ/LexUriServ.do?uri=COM:2013:0638:FIN:EN:PDF, 23.05.2019.

European Commission (2011), Communication from the Commission to the European Parliament, the Council, the European Economic and Social Committee and the Committee of the Regions, On security of energy supply and international cooperation - "The EU Energy Policy: Engaging with Partners beyond Our Borders", COM(2011) 539 final, Brussels, 07.09.2011, http://ec.europa.eu/transparency/regdoc/rep/1/2011/EN/1-2011-539-EN-F1-1. Pdf, 22.05.2019.

European Council (2013), Conclusions of the European Council (22 May 2013), https://www.consilium.europa.eu/uedocs/cms_data/docs/pressdata/en/ec/137197.pdf, 25.05.20190.

European Council (2011), Conclusions of the European Council (9 December 2011), http://europa. eu/rapid/press-release_DOC-11-8_en.htm, 25.05.2019.

Eurostat (2018), Energy, transport and environment indicators, Publications Office of the European Union, Luxembourg.

Geden O., Marcelis C., Maurer A., Perspectives for the European Union's External Energy Policy: Discourse, Ideas, Interests in Germany, the UK, Poland and France, Working Paper FG1, 2006/17, December 2006, SWP Berlin.

Heinecke E. (2016), Energieaussenpolitik der EU, Marburg.

Knodt M., Chaban N., Nielsen L. (2017), Bilateral Energy Relations between the EU and Emerging Powers. Mutual Perception of the EU and Brazil, China, India and South Africa, BadenBaden.

LNG in Europe (2018), An Overview of LNG Import Terminals in Europe, https://www.kslaw.com/ attachments/000/006/010/original/LNG_in_Europe_2018_-_An_Overview_of_LNG_Import_Terminals_in_Europe.pdf?1530031152, 30.10.2018.

Mogherini F. (2016), Shared Vision, Common Action: A Stronger Europe. A Global Strategy for the European Union's Foreign And Security Policy, June 2016, http://eeas.europa.eu/archives/ docs/top_stories/pdf/eugs_review_web.pdf, 27.05.2019.

Pollak J., Schubert S., Slominski P. (2010), Die Energiepolitik der EU, Wien. 
Reuters (2018), Türkei und Deutschland wollen engere Energiekooperation, 26.10.2018, https:// de.reuters.com/article/t-rkei-altmaier-energie-idDEKCN1N01H3, 30.05.2019.

Rompel S. (2015), Eine Energieaußenpolitik für die Europäische Union. Anspruch und Wirklichkeit, Baden-Baden.

Röhrkasten S. (2015), Antrieb für die deutsch-brasilianische Energiepartnerschaft. Die Regierungskonsultationen sollten den politischen Dialog zu erneuerbaren Energien stärken, "SWP Aktuell" 66, Juli 2015.

TFEU (2016), Consolidated version of the Treaty on the Functioning of the European Union, Official Journal of the European Union, C 202/171, 7.6.2016.

\section{Summary}

The article presents selected issues related to shaping the external dimension of the European Union's energy policy and the main directions and practice of Germany's energy policy. The beginnings, directions and instruments of the external dimension of EU energy policy are discussed, including problems limiting the effectiveness of external coordination of energy cooperation of the European Union Member States. In addition, the study presents Germany's position towards the external dimension of EU energy policy as well as the goals, shape and main instruments of Germany's energy relations with producers, consumers and transit countries of energy resources.

Key words: European Union, Germany, external dimension of energy policy, energy cooperation

\section{Zewnętrzny wymiar polityki energetycznej Unii Europejskiej a praktyka polityki energetycznej Niemiec}

\section{Streszczenie}

Artykuł prezentuje wybrane kwestie związane z kształtowaniem zewnętrznego wymiaru polityki energetycznej Unii Europejskiej oraz głównych kierunków i praktyki polityki energetycznej Niemiec. Omawiane są początki, kierunki i instrumenty zewnętrznego wymiaru polityki energetycznej UE, w tym także problemy ograniczające efektywność zewnętrznej koordynacji współpracy energetycznej państw członkowskich Unii Europejskiej. Ponadto opracowanie przedstawia stanowisko Niemiec wobec zewnętrznego wymiaru polityki energetycznej UE, jak również cele, kształt i kluczowe instrumenty relacji energetycznych Niemiec z producentami, konsumentami i państwami tranzytowymi surowców energetycznych.

Słowa kluczowe: Unia Europejska, Niemcy, zewnętrzny wymiar polityki energetycznej, współpraca energetyczna 
